\section{Tracking Thermal Pathways of Magma Ascent and Eruption Using Trace Element Partitioning in Sector Zoned Clinopyroxene}

\author{
ALICE MACDONALD ${ }^{1}$, TERESA UBIDE ${ }^{1}$, MATTEO \\ MASOTTA $^{2}$, SILVIO MOLLO ${ }^{3}$, ALESSIO PONTESILLI $^{4}$, \\ RUADHAN MAGEE ${ }^{1}$ AND JIAN-XIN ZHAO ${ }^{1}$ \\ ${ }^{1}$ The University of Queensland \\ ${ }^{2}$ University of Pisa \\ ${ }^{3}$ Sapienza - University of Rome \\ ${ }^{4}$ National Institute of Geophysics and Volcanology \\ Presenting Author: alice.macdonald@uq.edu.au
}

Igneous minerals provide valuable records of magmatic processes in active volcanoes, witnessing the conditions which lead up to eruptions. The solidification pathway of a magma plays a key role in eruption style and thus potential hazards, however discerning ascent processes from mineral records is not always straightforward. Different solidification pathways in a plumbing system will experience different cooling and degassing rates, which result in different degrees of magma undercooling $\left(\Delta \mathrm{T}=\mathrm{T}_{\text {liquidus }}-\mathrm{T}_{\text {crystallisation }}\right)$ and crystallisation conditions. Understanding how changing $\Delta \mathrm{T}$ is reflected by mineral chemistry and zoning is integral in our interpretation of magmatic histories.

Sector zoning in clinopyroxene, characterised by the presence of distinct crystal domains (low Al-Ti hourglass sectors and high Al-Ti prism sectors) which grow simultaneously, yet differ in chemistry, is strongly related to $\Delta \mathrm{T}$. Investigating these zonations in active volcano settings provides an opportunity to explore preeruptive processes associated with $\Delta \mathrm{T}$ changes for a range of eruption styles $^{[1]}$.

We apply a new REE $+\mathrm{Y} \Delta \mathrm{T}$ calibration, developed specifically for sector zoned clinopyroxenes using experimentally-derived trace element data, to a range of augitic clinopyroxene megacrysts $(>5 \mathrm{~mm})$, phenocrysts $(0.5-5 \mathrm{~mm})$ and microcrysts $(<0.5 \mathrm{~mm})$ from central conduit and eccentric eruptions at $\mathrm{Mt}$ Etna, Italy, to investigate differences in pre-eruptive processes and solidification pathways in the volcano plumbing system. We also apply the same calibration to clinopyroxene megacrysts erupted at Stromboli, Italy, for comparison. Results show that hourglass sectors typically record low $\Delta \mathrm{T}$ conditions $\left(<45^{\circ} \mathrm{C}\right)$, which aligns with previous experimental results based on major element partitioning ${ }^{[2]}$. Prism sectors, on the other hand, return higher $\Delta \mathrm{T}$ results, suggesting that these domains may be unreliable recorders of $\Delta \mathrm{T}$ due to enhanced uptake of highly charged cations. Additionally, clinopyroxene microcrysts return higher $\Delta \mathrm{T}$ than phenocrysts from the same eruption, highlighting the ability of clinopyroxene to record a range of magma crystallisation regimes.

Our data will be used to explore differences in polythermal and polybaric processes between eruption styles, and aim to better constrain magma ascent pathways prior to eruption.

[1] Ubide et al., Geochimica et Cosmochimica Acta, 251, 265- 